\title{
Integrated plant production - benefits and prospects
}

\section{Integrowana produkcja roślin - korzyści i perspektywy}

\author{
Danuta Sosnowska ${ }^{1}$, Piotr Sobiczewski ${ }^{2}$, Zbyszek Zbytek ${ }^{3}$, Jerzy H. Czembor ${ }^{4}$
}

\section{Summary}

Integrated plant production - a voluntary system of food production subjected to registration and inspection operations, and requiring from a producer to obtain a food quality certificate, has been operating in Poland since the 90 s of the last century. The system is based on the use of sustainably technical and biological progress in cultivation, fertilization and plant protection, with a particular attention on the protection of the environment and human health. The main element of the system is to use principles of Integrated Plant Management. Use of integrated plant production provides tremendous benefit to the Polish agriculture, because by implementation of the principles of good plant protection practice we produce safe food, protect the environment and increase biodiversity, as well as reduce expenditure on production.

Key words: integrated plant production; integrated plant protection

\section{Streszczenie}

Integrowana produkcja roślin - dobrowolny system produkcji żywności, podlegający rejestracji i czynnościom kontrolnym oraz wiążący się z koniecznością uzyskania przez producenta certyfikatu jakości żywności, funkcjonuje w Polsce od lat 90. ubiegłego wieku. System opiera się na wykorzystaniu w sposób zrównoważony postępu technicznego i biologicznego w uprawie, nawożeniu i ochronie roślin, przy zwróceniu szczególnej uwagi na ochronę środowiska i zdrowie ludzi. Podstawowym elementem systemu jest stosowanie zasad integrowanej ochrony roślin. Stosowanie systemu integrowanej produkcji roślin przynosi ogromne korzyści polskiemu rolnictwu, gdyż poprzez wprowadzanie zasad dobrej praktyki ochrony roślin produkujemy bezpieczną żywność, chronimy środowisko i zwiększamy bioróżnorodność, jak również zmniejszamy nakłady na produkcję.

Słowa kluczowe: integrowana produkcja roślin; integrowana ochrona roślin

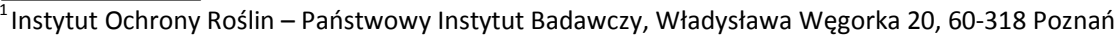

${ }^{2}$ Instytut Ogrodnictwa, Pomologiczna 18, 96-100 Skierniewice

${ }^{3}$ Przemysłowy Instytut Maszyn Rolniczych, Starołęcka 31, 60-963 Poznań

${ }^{4}$ Instytut Hodowli i Aklimatyzacji Roślin - Państwowy Instytut Badawczy, Radzików, 05-870 Błonie

*corresponding author: d.sosnowska@iorpib.poznan.pl
} 


\section{Wstęp / Introduction}

Na Światowym Forum Krajobrazu, które odbyło się w 2013 roku W Warszawie podkreślano, że w skali globalnej rolnictwo staje się sektorem strategicznym, ponieważ stawia się przed nim wyzwanie, jakim jest sprostanie zwiększającym się potrzebom żywieniowym świata. W obliczu rosnącej populacji istnieje potrzeba innowacyjnych rozwiązań, które pozwolą na zwiększenie produkcji rolniczej, ale jednocześnie będą przyjazne dla środowiska. Takim kryteriom odpowiada integrowana produkcja roślin, która jest dobrowolnym, krajowym systemem jakości żywności podlegającym rejestracji i czynnościom kontrolnym oraz wiążącym się z koniecznością uzyskania przez producenta certyfikatu jakości żywności. Obecnie działa w Polsce 7 jednostek certyfikujących upoważnionych przez wojewódzkich inspektorów ochrony roślin i nasiennictwa, którzy prowadzą także kontrolę zgodności działania tych jednostek z obowiązującymi przepisami Ustawy o środkach ochrony roślin (Ustawa 2013). Podstawowym elementem integrowanej produkcji jest integrowana ochrona roślin.

Praca przygotowana wspólnie przez Instytut Ochrony Roślin - Państwowy Instytut Badawczy (IOR - PIB), Instytut Ogrodnictwa (IO), Przemysłowy Instytut Maszyn Rolniczych (PIMR) oraz Instytut Hodowli i Aklimatyzacji Roślin - Państwowy Instytut Badawczy (IHAR - PIB) przedstawia korzyści i perspektywy dla polskiego rolnictwa wynikające ze stosowania integrowanej produkcji.

\section{Integrowana produkcja roślin / Integrated plant production}

System integrowanej produkcji roślin (IP - Integrowana Produkcja) funkcjonuje w Polsce od lat 90. ubiegłego wieku, a jego podstawą jest wykorzystanie w sposób zrównoważony postępu technicznego i biologicznego w uprawie, nawożeniu i ochronie roślin, przy zwróceniu szczególnej uwagi na ochronę środowiska i zdrowie ludzi. Bardzo ważne w tym systemie jest przestrzeganie zasad dobrej praktyki ochrony roślin (Pruszyński 1994, 1997).

System integrowanej produkcji został wprowadzony po raz pierwszy w wielkotowarowym sadownictwie przez Instytut Sadownictwa i Kwiaciarstwa (ISiK) w Skierniewicach (obecnie Instytut Ogrodnictwa) pod kierunkiem prof. Edmunda Niemczyka (Niemczyk 2001). W 1990 roku zorganizowano przy współpracy z byłym Towarzystwem Przyjaciół ISiK spotkanie organizacyjne poświęcone integrowanej produkcji jabłek. W następnym roku ukonstytuował się Zarząd Krajowy Integrowanej Produkcji Ogrodniczej i przy współudziale Ministerstwa Rolnictwa i Rozwoju Wsi opracowano założenia działalności Integrowanej Produkcji Ogrodniczej (IPO) w Polsce. Jednocześnie zespół pracowników ISiK opracował i opublikował pierwsze w Polsce „Wytyczne integrowanej produkcji jabłek" wraz z formalnymi załącznikami oraz pierwszy „Notatnik prowadzenia obserwacji i zabiegów w sadzie z integrowaną produkcją owoców na rok 1991". W kolejnych latach opracowano „Wytyczne IPO” także dla innych gatunków owoców. Od 1993 roku zapoczątkowano wydawanie certyfikatów IPO i przez 8 lat ISiK był jedyną instytucją w kraju posiadającą takie uprawnienia. Opracowano jednocześnie specjalne logo IPO, które sadownicy naklejali na jabłka i opakowania.

W celu upowszechniania i wdrażania systemu IPO pracownicy ISiK prowadzili szeroko zakrojoną działalność szkoleniową i upowszechnieniową. Łącznie do końca 2014 roku przeszkolono około 28000 osób.

Pierwsze działania $\mathrm{w}$ zakresie integrowanej produkcji warzyw w Polsce podjęto w Instytucie Warzywnictwa w Skierniewicach w podobnym okresie, jak w ISiK w przypadku owoców. Na początku opracowano zasady i wytyczne, zwłaszcza dotyczące upraw warzyw pod osłonami. Wydano szereg publikacji upowszechnieniowych, organizowano szkolenia i konferencje, a w 2000 roku rozpoczęto wydawanie certyfikatów. W latach 2001-2003 przeprowadzono 30 szkoleń, w których uczestniczyło ponad 1000 osób i wydano 300 certyfikatów producentom warzyw (Olszak i wsp. 2004).

W roku 2004 nadzór nad integrowaną produkcją roślin przejęła Państwowa Inspekcja Ochrony Roślin i Nasiennictwa (PIORiN). W latach 2010-2014 PIORiN wydał 8082 certyfikatów IP, w tym najwięcej z nich na jabłka.

\section{Integrowana ochrona roślin / Integrated plant protection}

Podstawowe cele strategiczne i perspektywy rozwoju rolnictwa w Polsce powinny uwzględniać światowe tendencje i wymogi wynikające z integracji Polski z Unią Europejską. Zgodnie z Dyrektywą Parlamentu Europejskiego i Rady 2009/128/WE z dnia 21 października 2009 roku ustanawiającej ramy wspólnotowego działania na rzecz zrównoważonego stosowania pestycydów (Dyrektywa 2009), wszyscy profesjonalni użytkownicy środków ochrony roślin są zobowiązani do stosowania od 1 stycznia 2014 roku zasad integrowanej ochrony roślin.

Integrowana ochrona roślin jest to sposób ochrony roślin przed organizmami szkodliwymi, polegający na wykorzystaniu wszystkich dostępnych metod, w szczególności niechemicznych, w sposób minimalizujący zagrożenie dla zdrowia ludzi, zwierząt i środowiska. Stosowanie tego sposobu ochrony opiera się na określonych zasadach, takich jak:

- nad chemiczne metody zwalczania organizmów szkodliwych przedkładanie metod biologicznych, fizycznych i innych niechemicznych, jeżeli zapewniają one ochronę przed organizmami szkodliwymi,

- zapobieganie występowaniu organizmów szkodliwych przez: płodozmian, właściwą agrotechnikę, uprawę odmian odpornych i/lub tolerancyjnych, zrównoważone nawożenie, wapnowanie i nawadnianie, środki zapobiegające introdukcji organizmów szkodliwych, ochronę i stworzenie warunków sprzyjających występowaniu organizmów pożytecznych.

Podstawą integrowanej ochrony roślin jest monitoring, sygnalizacja i prognozowanie występowania chorób i szkodników, a także profilaktyka. Jednym z działań służących wdrożeniu ogólnych zasad integrowanej ochrony roślin jest opracowanie metodyk, które stanowią pełny zestaw zaleceń opartych o wyniki najnowszych badań 
naukowych i dane z literatury, a ich wdrożenie do praktyki przyczynia się do zmniejszenia zużycia chemicznych środków ochrony roślin, a przez to uzyskania bezpiecznej dla konsumentów żywności. Metodyki obejmują wszystkie etapy produkcji roślinnej począwszy od właściwej lokalizacji stanowiska i przygotowania pola oraz wyboru odmiany, poprzez zabiegi agrotechniczne, do monitoringu i zwalczania chorób, szkodników i chwastów.

Do tej pory IOR - PIB opracował 30 metodyk integrowanej ochrony roślin (dla doradców i producentów) dla następujących upraw: pszenżyta ozimego i jarego, jęczmienia ozimego i jarego, łubinu, ziemniaka, pszenicy ozimej i jarej, żyta ozimego i jarego, kukurydzy, rzepaku ozimego i jarego, gorczycy, wierzby energetycznej, owsa, prosa, gryki, grochu siewnego, bobiku, komonicy, facelii, kapusty pastewnej, rzodkwi oleistej, mieszanek zbożowych i traw. Powstały również monografie opisujące podstawy integrowanej ochrony oraz zastosowanie integrowanej ochrony w uprawach rolniczych (Mrówczyński 2013a, b).

$\mathrm{Z}$ kolei IO opracował 25 metodyk integrowanej produkcji i 25 metodyk integrowanej ochrony roślin (dla doradców i producentów) dla następujących roślin sadowniczych: jabłoni, gruszy, śliwy, brzoskwini, wiśni, czereśni, truskawki, maliny, porzeczki i borówki wysokiej oraz roślin warzywnych: buraka ćwikłowego, kapusty pekińskiej i głowiastej, ogórka gruntowego i pod osłonami, szparaga, cebuli, kalafiora, marchwi, papryki, pomidora gruntowego i pod osłonami, sałaty pod osłonami i w gruncie. Stanowią one jeden $\mathrm{z}$ najważniejszych elementów w procesie wdrażania zasad integrowanej produkcji roślin ogrodniczych i uzyskiwania certyfikatów poświadczających odpowiednią jakość i bezpieczeństwo żywności (Łabanowska i Meszka 2011; Sobiczewski i Meszka 2013; Łabanowska 2014; Sobiczewski i wsp. 2015).

Na stronie internetowej Ministerstwa Rolnictwa i Rozwoju Wsi (MRiRW), a także odpowiednich Instytutów podległych Ministerstwu dostępne są metodyki integrowanej ochrony roślin dla upraw rolniczych, sadowniczych, warzywnych i specjalnych oraz grzybów jadalnych i lasów.

\section{Korzyści / Benefits}

Stosowanie systemu integrowanej produkcji roślin przynosi ogromne korzyści polskiemu rolnictwu, gdyż poprzez wprowadzenie zasad dobrej praktyki ochrony roślin zapewniona jest produkcja bezpiecznej żywności, wolnej od przekroczeń dopuszczalnych pozostałości środków ochrony roślin, metali ciężkich, azotanów i innych substancji szkodliwych. Ogromne znaczenie mają względy ekonomiczne, gdyż zmniejszają się nakłady na produkcję. Uprawa odmian o podwyższonej odporności np. na fuzariozę kłosów pszenicy pozwala ograniczyć straty wynikające $\mathrm{z}$ przekroczenia norm zawartości toksyn fuzaryjnych w ziarnie (Zalecenie Komisji 2006/576/WE, 2006/583/WE) w regionach zagrożonych tymi chorobami, a jednocześnie zmniejszyć zużycie chemicznych środków ochrony roślin i ograniczyć zanieczyszczenie środowiska. Dużym osiągnięciem IO jest wyhodowanie odmian jabłoni (Ligolina, Free Redstar, Melfree i Gold Milenium) odpornych na parcha jabłoni, genotypów porzeczki czarnej (Polares) genetycznie odpornych na wielkopąkowca porzeczkowego lub o wysokiej jakości owocach deserowych (Gofert), czy nowych, deserowych odmian truskawki (Grandarosa, Pink Rosa, Markat) wytrzymałych na mróz i mało podatnych na choroby grzybowe liści i wertycyliozę (Żurawicz i Kozik 2015). W dziedzinie hodowli roślin warzywnych na uwage zasługują najnowsze odmiany heterozyjne ogórka polowego (Zefir $\mathrm{F}_{1}$, Edyp $\mathrm{F}_{1}$, Ibis $\mathrm{F}_{1}$ ), które łączą wysoki stopień odporności na mączniaka rzekomego z innymi cechami użytkowymi (Kozik i wsp. 2015). Natomiast efektem badań w zakresie hodowli odpornościowej pomidora na czynniki biotyczne są mieszańce $\mathrm{F}_{1} \mathrm{z}$ kompleksową odpornością na najważniejsze choroby $\mathrm{W}$ uprawie pod osłonami: brunatną plamistość liści, wertycyliozę, fuzaryjne więdnięcie $\mathrm{i}$ fuzariozę zgorzelową oraz wirozę powodowaną przez wirusa mozaiki tytoniu (Bekas, Słonka, Perkoz, Pelikan, Tukan, Lelek, Klint, Kormoran, Cykada) (Nowakowska i Kozik 2013). Decyzja o wykonaniu zabiegów ochrony roślin jest podejmowana $\mathrm{w}$ oparciu o monitoring występowania organizmów szkodliwych, z uwzględnieniem progów ekonomicznej szkodliwości. Ogromnym plusem stosowania tego systemu jest także zwiększenie bioróżnorodności agrocenoz i co - bardzo ważne - świadomości społecznej producentów i konsumentów.

\section{Perspektywy / Prospects}

Ogromnym wyzwaniem dla naukowców w najbliższych latach będzie opracowanie innowacyjnych metod produkcji roślin, w tym nowoczesnych metod diagnostycznych do identyfikacji agrofagów i metod analitycznych do badania pozostałości środków ochrony roślin, jak również metod hodowlanych uwzględniających poszukiwanie źródeł odporności, a także innowacyjnych rozwiązań konstrukcyjnych maszyn rolniczych. Instytuty branżowe podległe MRiRW odgrywają zasadniczą rolę we wdrażaniu swoich badań naukowych do praktyki, jak również w kształtowaniu polskiej wizji wspólnej polityki rolnej i podnoszeniu konkurencyjności polskiego rolnictwa na świecie. Instytuty posiadają nowoczesną bazę badawczą w postaci najnowocześniejszych akredytowanych laboratoriów, wyposażonych w wysokiej klasy aparaturę, nowoczesne kompleksy szklarniowe i pola doświadczalne. Należą do najlepszych instytutów prowadzących badania, między innymi w zakresie ochrony upraw rolniczych, sadowniczych i warzywnych oraz w obszarze hodowli roślin i nasiennictwa.

W IOR - PIB i IO od wielu lat prowadzone są badania nad integrowaną produkcją upraw rolniczych, owoców i warzyw. W sposób całościowy obejmują one zagadnienia związane zarówno z uprawą, nawożeniem i pielęgnacją roślin, zbiorem i przechowalnictwem płodów, jak i szeroko rozumianą ochroną roślin, uwzględniającą również technikę wykonywania zabiegów ochrony roślin. W badaniach wykorzystywane są techniki molekularne oraz nowoczesne metody analityczne do wykrywania pozostałości środków ochrony roślin w płodach rolnych, paszach, glebie i wodzie. W pracach nad hodowlą nowych 
odmian szczególny nacisk kładzie się na uzyskanie genotypów odpornych lub tolerancyjnych na choroby i szkodniki. Takie multidyscyplinarne podejście jest ukierunkowane na wykorzystanie metod proekologicznych, w tym naturalnej odporności roślin i czynników oporu środowiska. Zasadniczy cel to opracowanie sposobów produkcji bezpiecznej żywności, przy jak największym ograniczeniu zagrożeń dla otoczenia.

W najbliższych latach $\mathrm{w}$ zakresie postępu biologicznego ważne zadania stoją przed IHAR - PIB oraz IO. Oczekuje się, że nowe technologie odegrają znaczącą rolę W osiąganiu postępu biologicznego roślin poprzez zróżnicowanie i poszerzenie puli genowej o geny niedostępne $\mathrm{w}$ genomach przenoszonych generatywnie oraz skrócenie czasu potrzebnego do uzyskania nowej jakości genetycznej. Zastosowanie w hodowli nowoczesnych technologii, w tym kultur in vitro, markerów molekularnych, markerów biochemicznych, transgenezy, genetycznej modyfikacji roślin oraz mikrometod do oceny jakości materiału roślinnego na wczesnych etapach hodowli, umożliwi skrócenie cyklu hodowlanego, świadomy i monitorowany transfer genów, zwiększenie efektywności selekcji, a w konsekwencji - znaczące obniżenie kosztów wyhodowania nowych odmian.

Rozwój biologii molekularnej, a szczególnie technologii markerowych oraz narzędzi bioinformatycznych umożliwiających analizę dużej liczby danych uzyskiwanych dla szerokiego typu populacji mapujących sprawia, że zmienia się podejście do selekcji materiałów roślinnych dla potrzeb hodowli. Przykładem jest tu wykorzystanie w hodowli map genetycznych jabłoni i truskawki skonstruowanych w IO (Keller-Przybyłkowicz i Korbin 2014). Tego typu badania dostarczają nie tylko nowych informacji o genetycznym uwarunkowaniu obserwowanej zmienności cech użytkowych roślin, włączając te, które warunkują odporność na patogeny i szkodniki, ale także wskazują na możliwość wykorzystania użytecznych technik pomocnych w prowadzeniu selekcji roślin w oparciu o genotyp, a nie tylko na podstawie obserwacji fenotypowych. Rozwijane są liczne systemy markerowe, które mogą mieć różnorakie zastosowanie w hodowli. Markery DNA ułatwiają dobór materiału wyjściowego oraz identyfikację odmian w hodowli roślin wieloletnich, takich jak: jabłoń, śliwa, wiśnia, czereśnia, porzeczka, malina, czy truskawka (Korbin i wsp. 2002; Kuras i wsp. 2013). Mają one też praktyczne zastosowanie głównie w hodowli odpornościowej, takich gatunków jak: pszenica, pszenżyto (rdza brunatna, rdza żółta, septorioza kłosów, fuzarioza kłosów) (Błaszczyk i Chełkowski 2005; Czembor i wsp. 2014; Radecka-Janusik i Czembor 2014), jabłoń (parch jabłoniowy, zaraza ogniowa) (Keller-Przybyłkowicz i wsp. 2009), truskawka (wertycylioza i inne choroby) (Korbin 2011) i wiele innych.

Odrębną możliwość stwarza selekcja genomowa. Ostatnie lata przyniosły zastosowanie wielu nowoczesnych technik genomiki funkcjonalnej umożliwiających badanie materiału roślinnego na szeroką skalę, co prowadzi do dużej ilości danych dotyczących jednego procesu. Jest to w opozycji do wcześniejszych podejść doświadczalnych polegających na analizie ekspresji jednego genu, szukaniu funkcji poszczególnych białek, czy charakterystyce kon- kretnych metabolitów. Globalna analiza profilu ekspresji genów to narzędzie służące do badania różnic w poziomie ekspresji między układem kontrolnym i układem poddanym dowolnej modyfikacji bądź stymulacji, czego przykładem może być prowadzona w IO analiza transkryptomu (Illumina-Solexa) truskawki w układzie roślinaVerticillium dahliae (Jęcz i wsp. 2013). Dzięki zastosowaniu tej techniki uzyskuje się jednorazowo dużą liczbę danych, co pozwala na przeprowadzenie szeroko zakrojonych porównań, poszukiwanie niedostrzegalnych w inny sposób powiązań i korelacji oraz identyfikację nowych czynników zaangażowanych w badane procesy.

Nowoczesne rolnictwo dzisiaj musi opierać się na fachowej wiedzy i wdrażać nowe technologie pozwalające na opłacalność produkcji w gospodarstwie $\mathrm{z}$ jednoczesnym spełnieniem wymogów ochrony środowiska i zachowania bezpieczeństwa żywności. Przyszłością jest rolnictwo precyzyjne, które można zdefiniować jako zespół technologii, który tworzy kompleksowy system rolniczy, dostosowując w jego ramach poszczególne elementy agrotechniki do zmiennych warunków na poszczególnych polach uprawnych. Wykorzystanie systemu jest możliwe w całym cyklu uprawy roślin (Doruchowski 2008). Prowadzenie produkcji opiera się na wykonywaniu zabiegów w odpowiednim czasie, przy zastosowaniu właściwej, jak najmniejszej ilości środków zgodnie z zasadami dobrej praktyki ochrony roślin (Doruchowski i wsp. 2015). Dużym osiągnięciem IO jest skonstruowanie rodziny opryskiwaczy tunelowych pozwalających na maksymalne ograniczenie strat środków ochrony roślin, przy jednocześnie bardzo wysokiej skuteczności ochrony i zastosowaniu zredukowanych dawek (Holownicki i wsp. 1995). Maszyny i urządzenia do zmiennej aplikacji są nieodłącznym elementem realizacji rolnictwa precyzyjnego. Ogromną rolę w opracowaniu nowych konstrukcji maszyn w aspekcie ograniczenia ich negatywnych oddziaływań na środowisko naturalne ma PIMR w Poznaniu.

Rozwój rolnictwa zrównoważonego, w tym w szczególności rolnictwa ekologicznego, przyczynił się do podjęcia działań w zakresie opracowania innowacyjnego rozwiązania - narzędzia do kompostowania organicznych odpadów produkcyjnych. Opracowano maszynę, która dzięki procesowi tlenowego rozkładu odpadów organicznych pozwala uzyskać w ciągu kilku tygodni materiał o bardzo wysokich wartościach nawozowych, czysty pod względem fitosanitarnym oraz łatwy i ekonomiczny w transporcie i rozrzucaniu na polu (Dach i Zbytek 2000).

W PIMR opracowano innowacyjne rozwiązania maszyn do niszczenia chwastów i samosiewów podczas uprawy pożniwnej (kultywatory ścierniskowe, kompaktowe brony talerzowe, brony mulczowe). Obok klasycznych rozwiązań kultywatorów ścierniskowych (Talarczyk i Zbytek 2009) w instytucie opracowano agregat do bezorkowej uprawy roli (Zbytek i Talarczyk 2008). Głównymi elementami roboczymi są zęby głębosza, umożliwiające spulchnienie gleby w dużym zakresie głębokości. Z kolei opracowana i przebadana w instytucie kompaktowa brona talerzowa jest szczególnie przydatna do płytkiej uprawy pożniwnej, zapewniając bardzo dobre wymieszanie ścierniska z glebą i pobudzenie do kiełkowania nasion osypanych podczas zbioru. 
Podstawowym zabiegiem ograniczającym zachwaszczenie jest bronowanie zasiewów. W tym zakresie PIMR opracował nowe rozwiązania konstrukcyjne maszyn do mechanicznej ochrony roślin wysiewanych w wąskie międzyrzędzia (zboża), w szczególności wielofunkcyjne zestawy bron chwastowników do upraw płaskich i redlinowych.

W PIMR zrealizowano prace wdrożeniowe dotyczące nowych rozwiązań maszyn do mechanicznego zwalczania chwastów w uprawach roślin wysiewanych w szerokie międzyrzędzia. Opracowano pielnik szczotkowy z aktywnymi elementami roboczymi do prowadzenia mechanicznych zabiegów pielęgnacyjnych w uprawach warzywnych (pielnik szczotkowy) (Zbytek i Talarczyk 2008). Cechą charakterystyczną tego rozwiązania jest zastosowanie elementów roboczych $\mathrm{w}$ postaci tarczy $\mathrm{z}$ segmentami szczotek wykonanych z polipropylenu. Tarcza ze szczotkami agresywnie oddziaływuje na chwasty, zdzierając i wyrywając je z gleby. Zespół szczotek osłonięty jest osłoną pełną, wykonaną z blachy, która ochrania operatora przed wyrzutem kamieni. Dzięki zastosowaniu płynnej regulacji kół podporowych uzyskuje się głębokość pracy od 15 do $45 \mathrm{~mm}$.

W zakresie ograniczenia stosowania chemicznych środków ochrony na plantacjach uprawianych roślin w PIMR wspólnie z IOR - PIB opracowano technologię ochrony roślin wysokich, takich jak kukurydza czy rośliny energetyczne $\mathrm{w}$ późnych fazach wzrostu, kiedy nieskuteczne jest użycie dotychczas stosowanych technologii, ponieważ głębokość penetracji łanu przez strumień rozpylonej cieczy technologicznej jest niewystarczająca. Zastosowano naddźwiękową prędkość strugi, która wykazuje się zdolnością penetracji łanu, nawet zwartego, na głębokość co najmniej 2,5 m. Dodatkowo, strumień aerozolu ładowany jest elektrostatycznie, co polepsza wskaźnik pokrycia roślin preparatem zarówno pod względem równomierności (zwłaszcza dolne powierzchnie liści), jak i ilości cieczy osadzającej się na roślinach.

W najbliższych latach w zakresie postępu technicznego PIMR podejmie działania nad opracowaniem nowych maszyn rolniczych charakteryzujących się innowacyjnymi rozwiązaniami $\mathrm{z}$ zastosowaniem mechatroniki, nastawionymi na energooszczędność i ochronę środowiska.

$\mathrm{W}$ celu rozwoju integrowanej produkcji roślin konieczne są działania upowszechniające ten system, w szczególności szkolenia, konferencje tematyczne, wydawanie ulotek i artykułów sponsorowanych $\mathrm{w}$ prasie branżowej. Zadania te realizować będą instytuty branżowe. W latach 2001-2003 IO przeprowadził 30 szkoleń, w których uczestniczyło ponad 1000 osób, w tym 63 instruktorów. Wydano 300 certyfikatów (Olszak i wsp. 2004). W latach 2005-2014 łącznie IO przeszkolił ponad
15 tysięcy osób i przeprowadził 14 konferencji ogólnopolskich. IOR - PIB w ramach Programu Wieloletniego w latach 2011-2015 zorganizował 20 szkoleń w różnych regionach kraju. Tematyka szkoleń oraz wydrukowane materiały upowszechnieniowe obejmowały informacje praktyczne dotyczące integrowanej ochrony roślin, zgodnie $\mathrm{z}$ najważniejszymi aktami prawa krajowego i międzynarodowego. Efektem praktycznym szkoleń było wyposażenie doradców, producentów rolnych i inspektorów ochrony roślin i nasiennictwa (około 1700 osób) w odpowiednią wiedzę praktyczną oraz materiały pomocnicze wspomagające podejmowanie decyzji o celowości, terminie i rodzaju prowadzonej ochrony roślin. Uczestnicy szkoleń otrzymali certyfikaty o ich ukończeniu.

\section{Podsumowanie / Summary}

W Polsce system integrowanej produkcji roślin wprowadzany jest od ponad 20 lat. Należy podkreślić, że w latach 2007-2014 eksport rolno-spożywczy w Polsce wzrósł ponad dwukrotnie z 10,1 mld euro do 21,3 mld euro, co również świadczy o rozwoju i ogromnym znaczeniu sektora rolnictwa w gospodarce kraju. Na tle Europy polskie rolnictwo wyróżnia się szczególnie wysokim udziałem w produkcji niektórych artykułów rolnych. Według danych Głównego Urzędu Statystycznego w Polsce produkuje się średnio 26,2 mln ton zbóż, przy czym wielkość ta waha się od 21,8 do ponad $29 \mathrm{mln}$ ton. W zależności od roku, udział produkcji zbóż w Polsce w stosunku do Unii Europejskiej wynosi ponad 6,5\%, a w stosunku do produkcji zbóż na świecie ponad $1 \%$. Ponadto Polska jest największym producentem jabłek i pieczarek.

Podstawą prawidłowego funkcjonowania systemu integrowanej produkcji roślin jest wiedza, systematycznie uzupełniana dzięki prowadzonym badaniom naukowym, których wyniki są wdrażane do praktyki rolniczej. Wiąże się to z koniecznością ciągłego dokształcania przez producentów, zarówno $\mathrm{w}$ ramach samokształcenia, jak i poprzez uczestnictwo w różnego rodzaju kursach, szkoleniach i konferencjach. Efektem ich wysokich kwalifikacji są produkty o najwyższych parametrach jakościowych, bez pozostałości środków ochrony roślin przekraczających dopuszczalne normy oraz posiadające wysokie wartości prozdrowotne, smakowe, itp.

W nowoczesnym rolnictwie, które musi spełniać rosnące wymagania jakościowe nie wystarczy przestrzegać tradycyjnych zaleceń uprawowych. Tylko integrowana produkcja roślin daje gwarancję efektywnego gospodarowania.

\section{Literatura / References}

Błaszczyk L., Chełkowski J. 2005. Geny odporności na patogeny w genomie pszenicy. s. 139-157. W: „Genomika i bioinformatyka roślin" (J. Chełkowski, G. Koczyk, red.). Instytut Genetyki Roślin PAN, Poznań, 217 ss.

Czembor H.J., Domeradzka O., Czembor J.H., Mankowski D.R. 2014. Virulence structure of the powdery mildew (Blumeria graminis) population occurring on triticale (x triticosecale) in Poland. Journal of Phytopathology 162 (7-8): 499-512. DOI: 10.1111/jph.12225

Dach J., Zbytek Z. 2000. Założenia do nowej technologii kompostowania obornika. Prace Przemysłowego Instytutu Maszyn Rolniczych 45 (4): 5-7. 
Doruchowski G. 2008. Postęp i nowe koncepcje w rolnictwie precyzyjnym. Inżynieria Rolnicza 9 (107): 19-31.

Doruchowski G., Hołownicki R., Godyń A. 2015. Poradnik dobrej praktyki ochrony roślin - ochrona wód przed zanieczyszczeniami miejscowymi. Wyd. III. Instytut Ogrodnictwa, Skierniewice, 96 ss.

Dyrektywa 2009. Dyrektywa Parlamentu Europejskiego i Rady 2009/128/WE z dnia 21 października 2009 roku ustanawiająca ramy wspólnotowego działania na rzecz zrównoważonego stosowania pestycydów. Dz. Urz. UE L 309 z 24.11.2009, tom 52, str. 71. DOI: 10.3000/17255139.L_2009.309.pol

Holownicki R., Doruchowski G., Godyn A. 1995. Efficient spray deposition in the orchard using a tunnel sprayer with a new concept of air jet emission. Acta Horticulturae 422: 284-288.

Jęcz T., Strączyńska K., Korbin M. 2013. Analiza transkryptomu truskawki pod kątem poszukiwania genów odpowiadających za reakcję roślin na zakażenie przez Verticillium dahliae. s. 72. Ogólnopolska Ogrodnicza Konferencja Naukowa „Ziemia, Roślina, Człowiek". Kraków, 11-12.09.2013, 214 ss.

Keller-Przybyłkowicz S., Korbin M. 2014. Identification of four new EST-based markers on the apple (Malus $\times$ domestica) genetic map. Journal of Horticultural Research 22 (1): 93-100. DOI: 10.2478/johr-2014-0011

Keller-Przybyłkowicz S., Lewandowski M., Korbin M. 2009. Molecular screening of apple (Malus domestica) cultivars and breeding clones for their resistance to fire blight. Journal of Fruit Ornamental Plant Research 17 (2): 31-43.

Korbin M. 2011. Molecular approaches to disease resistance in Fragaria spp. Journal of Plant Protection Research 51 (1): 23-28.

Korbin M., Kuras A., Żurawicz E. 2002. Fruit plant germplasm characterization using molecular markers generated in RAPD and ISSR-PCR. Cellular and Molecular Biology Letters 7 (2B): 785-794.

Kozik E.U., Kłosińska U., Kamiński P., Nowakowska M. 2015. Hodowla z serca Polski. Warzywa i owoce miękkie 6: 62-66.

Kuras A., Antonius K., Kalendar R., Kruczyńska D., Korbin M. 2013. Application of DNA marker techniques to distinguish between five apple (Malus $\mathrm{x}$ domestica Borkh.) cultivars and their sports. Journal of Horticultural Science and Biotechnology 88 (6): 790-794. DOI: 10.1080/14620316.2013.11513040

Łabanowska B. (red.). 2014. Metodyki prowadzenia obserwacji występowania wybranych organizmów szkodliwych i oceny potrzeby wykonywania zabiegów ochrony roślin. Instytut Ogrodnictwa, Skierniewice, $108 \mathrm{ss}$.

Łabanowska B.H., Meszka B. 2011. Pestycydy zalecane w Integrowanej Produkcji owoców jagodowych i jabłek, których pozostałości nie może być w owocach i przetworach. Materiały XIV Ogólnopolskiej Konferencji Sadowniczej „Przyszłość uprawy truskawki, maliny, porzeczki czarnej i borówki wysokiej w Polsce oraz ważne informacje dla producentów jabłek”. Lublin, 8 grudnia 2011: 64-67.

Mrówczyński M. (red.). 2013a. Integrowana ochrona upraw rolniczych. Podstawy integrowanej ochrony. Tom I. PWRiL, Poznań, 153 ss.

Mrówczyński M. (red.). 2013b. Integrowana ochrona upraw rolniczych. Zastosowanie integrowanej ochrony. Tom II. PWRiL, Poznań, 286 ss.

Niemczyk E. 2001. Ten years of IFP in Poland - theory and practice. IOBC/WPRS Bulletin 24 (5): 33-37.

Nowakowska M., Kozik E.U. 2013. Cykada F1 - heterozyjna odmiana pomidora hodowli Instytutu Ogrodnictwa. Oferta Wdrożeniowa. Konferencja Nauka - Praktyce. Instytut Ogrodnictwa, Skierniewice, 10 grudnia 2013: 83-84.

Olszak R.W., Niemczyk E., Nawrocka B., Dobrzański A., Robak J. 2004. Stan aktualny i perspektywy integrowanej produkcji owoców i warzyw w Polsce. [The present status and perspectives of integrated production of fruits and vegetables in Poland]. Progress in Plant Protection/Postępy w Ochronie Roślin 44 (1): 272-279.

Pruszyński S. 1994. Ochrona roślin w integrowanych technologiach produkcji. Materiały 34. Sesji Naukowej Instytutu Ochrony Roślin, cz. 1: 71-78.

Pruszyński S. 1997. Znaczenie ochrony roślin w rozwoju rolniczych technologii produkcji. [Plant protection in agricultural production technology]. Progress in Plant Protection/Postępy w Ochronie Roślin 37 (1): 19-26.

Radecka-Janusik M., Czembor P.C. 2014. Genetic mapping of quantitative trait loci (QTL) for resistance to Septoria tritici blotch in a winter wheat cultivar Liwilla. Euphytica 200: 109-125. DOI: 10.1007/s10681-014-1157-6

Sobiczewski P., Łabanowska B.H., Miszczak A., Robak J. 2015. Integrowana ochrona roślin ogrodniczych gwarancją bezpiecznej żywności. Materiały Ogólnopolskiej Konferencji Upowszechnieniowo-Wdrożeniowej „Innowacyjne technologie dla polskiego ogrodnictwa nauka - praktyce". CBR, Warszawa, 23 kwietnia 2015: 27-29.

Sobiczewski P., Meszka B. 2013. Aktualne problemy ochrony roślin sadowniczych przed chorobami. Materiały 56. Ogólnopolskiej Konferencji Ochrony Roślin Sadowniczych. „Integrowana ochrona roślin - standardem od 2014 roku”. Ossa, 14-15.02.2013: 12-17.

Talarczyk W., Zbytek Z. 2009. Uniwersalna konstrukcja kultywatora podorywkowego i obsypnika do ziemniaków. Zeszyty Problemowe Postępów Nauk Rolniczych 543: 355-364.

Ustawa 2013. Ustawa z dnia 8 marca 2013 r. o środkach ochrony roślin (art. 61, ust. 1). Dz. U. z 2013 r. poz. 455 , z 2014 r. poz. 822 , 827.

Zbytek Z., Talarczyk W. 2008. Badania funkcjonalne, jakości pracy i energetyczne pielnika szczotkowego. Problemy Inżynierii Rolniczej 16 (2): 103-108.

Zalecenie Komisji z dnia 17 sierpnia 2006 r. w sprawie obecności deoksyniwalenolu, zearalenonu, ochratoksyny A, T-2 i HT-2 oraz fumonizyn w produktach przeznaczonych do żywienia zwierząt (2006/576/WE). Dz. Urz. UE L 229/7 z 23.08.2006.

Zalecenie Komisji z dnia 17 sierpnia 2006 r. w sprawie zapobiegania występowaniu i ograniczania występowania toksyn Fusarium w zbożach i produktach zbożowych (2006/583/WE). Dz. Urz. UE L 234/35 z 29.08.2006.

Żurawicz E., Kozik E. 2015. Znaczenie hodowli roślin ogrodniczych w tworzeniu i wdrażaniu postępu biologicznego w polskim sadownictwie i warzywnictwie. Materiały Ogólnopolskiej Konferencji Upowszechnieniowo-Wdrożeniowej „Innowacyjne technologie dla polskiego ogrodnictwa nauka - praktyce”. CBR, Warszawa, 23 kwietnia 2015: 13-15. 